研究論文 反公害住民運動における経験の交流

一電話交換台としての自主講座「公害原論」とともに一

\author{
友澤悠季 \\ 法政大学サステイナビリティ研究所客員研究員
}

\begin{abstract}
Sharing the Experiences from Multiple Anti-pollution Movements
- Contribution of the Jishu-koza KOGAI Genron as a Telephone Switchboard of Experiences -
\end{abstract}

\author{
Yuuki TOMOZAWA \\ Hosei University \\ (受理日 2015年 5 月 31 日)
}

This article discusses the learning experiences that the Japanese anti-pollution movements from the 1960s- 70's inevitably imparted. Jun Ui (1932-2006), who was a famous scientist, critic, and activist in the field of pollution problems, especially Minamata disease, deeply respected non-academic people who struggled to tell neighbors about the pollution problem in their community. He respected them like the master of the science movement. They did not accept development plans introduced from outside of the community. They voluntarily researched about the possibilities of the pollution and attempted to create an arena for discussion. The learning activities raised the will to disclose the covert social discrimination structure, and change the social system. Those movements were connected to several networks which have the ability to support them by supplying scientific information about pollution problems. By the instrumentality of the network, activists were able to share their multiple experiences in different places, and felt great sympathy. This paper describes the "Jishu-koza KOGAI Genron (a voluntary public lecture on pollution problems by citizens and students)" at The University of Tokyo as the one of those networks. Ui often called Jishu-koza "a telephone switchboard of experiences" because the main job of the members in Jishu-koza was to introduce an action group to another one that has similar issues. It is an important fact that they exchanged their experiences including not only scientific information but also their failures to each other through the Jishu-koza network. It is necessary to reconsider the meaning of this intercommunication.

Key words: KOGAI, anti-pollution movements, citizen's movement, experience, voluntary network

\section{I 宇井純・自主講座「公害原論」・住民運動}

「公害」をめぐる重要な論点を社会に示しつづ けた宇井純（1932～2006）は、公害反対や開発 反対を訴えた住民運動の学習活動がもつ意味を次
のように評価している。

住民運動は、実質的に社会教育の機能を果たし ている。

現在の日本の社会はなにしろうまくできていて、

問い合わせ先 Email:yuukitomozawa@gmail.com 
問題をたくさん抱えながらも、考えなければ大 体気がつか女うちに、何事も事もなく進行して しまう。実は重層的な差別社会で、特定の目に見 えにくいところに、まとめて問題が押しつけら れているのである。このために、自分が当事者に なるまでは、問題の所在すら気づかないのが普 通であり、当事者になってはじめて、自発的な 学習、勉強がはじまる。(宇井1980=2014-2 248)

「公害」の根元には、科学技術の展開と結びつい た経済活動がある。ゆえに「公害」に向き合おう とすると、必ずそこに学習がともなう。1960年代の 公害被害の顕在化にもかかわらず、1970年代、日 本のあちこちで、全国総合開発計画・新産業都市 計画などが具体化していった。臨海工業地帯を造 成し、石油化学コンビナートや火力・原子力発電 所を建設しょうとする開発計画は、ほとんどの場 合、「無公害」をうたって地域に持ち込まれた。「な ぜ、わたしたちがこのような公害源の受け入れを迫 られるのか」という疑問を抱いた住民は、その瞬間 に、当事者になった。自分たちのところに押しつけ られた問題がなんであるかを知ろうとする行為は、 ただ専門用語を頭にいれるだけにとどまらず、自分 の生きている社会がどのような差別構造のうえに成 り立っているのか、自分の内面にもその構造は入り 込んではいまいか—という深層の問い直しにつ ながっていった。公害反対の住民運動は、ほとん どの場合、公害学習運動でもあった。

宇井の専門は衛生工学、とくに水処理の技術分 野であって、教育学ではない。しかし、熊本と新 潟の 2 つ水俣病事件の目撃者、告発者として、宇 井は、「公害」を生んだ原因の一つは、人間を差別 し序列化する科学技術信仰であると考え（宇井 1973a=2014-1 308)、学問と教育のあり方について も精力的に発言した。そして、学問と教育を担うも の、とりわけ大学人の考えや行動の質が、「公害」 の発生や拡大に加担すると見てとったときには、仮 借ない批判を浴びせた。矛先は、おもに大学とい う「象牙の塔」に向けられていたが、その対極にあっ たのが、住民運動当事者らの行う学習行為であっ た。宇井と住民運動との交流は1960年代に始まる
が、とくに1970年から 85年まで東京大学で開かれ た自主講座「公害原論」は、宇井に、さまざまな 地域での「全人格的な信頼感のもてる人びと」(宇 井1981=2014-3 303）との出会いをもたらし、在野 でとりくまれる教育・学習活動への具体的期待と 信頼（あるいは憧憬）を育てるきっかけとなった。

自主講座「公害原論」は、「公害教育」史におい て、成人の「公害にかかわる学びの場」のひとつ に数えられる（安藤2015 60）。この講座の主眼は、 「公害」の現実を知らせることはもちろん、全国各 地で取り組まれている進行形の反公害住民運動か ら当事者を招き、人を、地域を、そしておのおのの 学習活動の内容を共有することに置かれた。ある 時期以降は、各地の住民運動の存在なしには、自 主講座「公害原論」は成り立たなかったといっても よい。そこではいったいどんな学びが行われていた のか。本稿の目的は、自主講座「公害原論」の成 立と展開をふりかえり、その場に刻まれた宇井純や 実行委員会の人びとの精神を跡づけること、そし て、自主講座とつながりをもった各地の住民運動の もつ学びの性格を考えてみることである。

\section{II 自主講座「公害原論」}

\section{1 前史}

自主講座「公害原論」はどのように始まったの か。その前史は、場（「自主講座」）を準備した東 京大学工学部助手会と、中身 (「公害原論」) を準 備した宇井純という、二つの存在から読み解くの が妥当である。

工学部助手会とは、東大闘争で学生が行った東 大批判を受けて、工学部の助手有志が1969年に 発足させた会である。当時、助手も教授と同様に、 講義の枠を獲得し、その中で東大解体をめざそう との考えがあり、これが「自主講座」の発案につ ながって、最初のスピーカーとして宇井純に白羽 の矢が立った。宇井でうまくいけばまた別の助手 が続く想定であったが、思いがけず宇井の話が評 判を呼び、後に続く助手も出にくく、けっきょく この自主講座は“宇井純が主宰する「公害原論」” として、同時代の社会に影響力をもつことになった1)。 助手会は以降「黒衣」に徹して、教室の確保など 
を支え続けた（依田ほか1991 445-449）。

宇井純は、1932年、東京に生まれた。茨城県を 経て栃木県壬生に移住し、1945年4月に旧制栃木 中学校に入学、夏に終戦。食料不足の中、一家で 開拓団に参加し、農業中心の暮らしを経験する。 高価だった化学肥料をできるだけ安くする研究を したいと、1951年4月東京大学理科 I 類に入学した が、すぐにそれは無理だと分かり、塩化ビニルに 関心の先を切り替えて、1956年4月、日本ゼオン株 式会社に入社。1959年に退社し、同年4月に東京 大学大学院応用化学研究生になる。この頃、熊本 県水俣市での「奇病」発生のうわさを耳にし、か つてゼオンの工場で、触媒に使用していた水銀入 りのヘドロを処理せず下水に流した経験を思い出 した宇井は、通産省や経済企画庁などを訪ね、「奇 病」の原因に関する情報を集めてまわった。次いで、 大阪の猪飼野にあるゴムや塩ビの加工業者に技術 的な助言をするアルバイトで得た旅費を使って、水 俣に行くようになった（宇井1997 74-105）。1962年 には、写真家の桑原史成とともに、チッソ付属病院 での猫実験の事実をつかみ、工場排水が水俣病の 原因であるとの確信を得るが、すぐに公表はできな かった。宇井は「現代技術史研究会」というサー クルの会誌に、1963年から、「富田八郎」というぺ ンネームで調查内容を連載し始めた2)。1965年4月、 東大工学部都市工学科の助手となった宇井は、 6 月、新潟水俣病（当初、第二水俣病と呼ばれた） 発生の報に接する。再発を止められなかったとの 深い悔恨とともに、宇井はペンネームの使用をや め、その後始まる新潟水俣病第一次訴訟への協力 と、公害問題に関する社会的発信をはじめた。

東大助手としての宇井は、1966年秋に一度、都 市問題に関する講義の一環として、公害の歴史と 事例について大学院で講義する機会を与えられた ことがあり、これを「公害原論」と名付けた。ヨー ロッパ留学（1968～69年秋）から帰国した宇井は 再度、公害の講義を命ぜられたが、「社会的な価値 判断を含まない、純粋に技術的な対策にだけ限定 するよう注文がついた」ため、腹に据えかねて断り、 「それくらいなら市民を相手に公開で自分の学問を 世に問う」(宇井1979=2014-1 261) と宣言してしまっ
た。1970年春、和光大学非常勤講師としてふたた び自由な内容の「公害原論」を講義し、好感触を 得たことが、のちの自主講座への助走となった。

宇井にとって、「公害」を語ることは、自身の 価值判断が水俣病事件との出会いによって根底か ら覆ったことを語ることにほかならない。「科学 技術をもって生活を豊かにしようと出発した私の 青年期は、水俣病によってその基盤がすでに砕か れていた」宇井は、「せめてできること」は、「身 につけてきた科学と技術なるものを裸にして、そ れが公害を導く必然性を誰の目にも見えるように はっきりさせ、私の 30 年歩んだ道を今後くり返 させないようにすることだろうか」と考えた（宇 井 1971=2014-1 31）。宇井の来歴からくる積年の 思いが、自主講座の場に注がれた。

\section{2 「開講のことば」の引カ}

1970 年 10 月 12 日、夜 6 時からの第 1 回目は、 受付に家族の手も借りながら、工学部都市工学科 8 号館 82 号教室で行われた。何人集まるか見当が つかず、3人集まれば開講しようと決めて臨んだ が、実際には 300 人あまりが詰め掛けて、教室に 入りきれないほどとなり、新聞記者やテレビカメ ラも入って、盛況となった。

その引力のもとはなんだったか。多くの人の心に 刻まれたのはやはり、宇井が開講に先立って書い た「開講のことば」だろう3)。以下がその初出とみ られる『助手会ニュース』No.3掲載の全文である。

公害の被害者と語るときしばしば問われるも のは、現在の科学技術に対する不信であり、憎悪 である。衛生工学の研究者としてこの問いをうけ るたびに我々が学んで来た科学技術が、企業の 側からは生産と利潤のためのものであり、学生に とっては立身出世のためのものにすぎないことを 痛感した。その結果として、自然を利益のため に分断、利用する技術から必然的に公害が出て 来た場合、我々が用意できるものは同じように自 然の分断、利用の一種でしかない対策技術しか なかった。しかもその適用は、公害という複雑な 社会現象に対して、常に事後の対策としてしか 
なされなかった。それだけではない。個々の公 害において、大学および大学卒業生はほとんど 常に公害の激化を助ける側にまわった。その典 型が東京大学である。かつて公害の原因と責任 の究明に東京大学が何等かの寄与をなした例と いえば、足尾鉱毒事件をのぞいて皆無であった。 建物と費用を国家から与えられ、国家有用の 人材を教育すべく設立された国立大学が、国家 を支える民衆を抑圧・差別する道具となって来 た典型が東京大学であるとすれば、その対極に は、抵抗の拠点としてひそかにたえず建設され たワルシャワ大学がある。そこでは学ぶことは 命がけの行為であり、何等特権をもたらすもの ではなかった。

立身出世のためには役立たない学問、そして 生きるために必要な学問の一つとして、公害原 論が存在する。この学問を潜在的被害者である 我々が共有する一つの方法として、たまたま空 いている教室を利用し、公開自主講座を開くこ ととした。この講座は、教師と学生の間に本質 的な区別はない。修了による特権もない。ある ものは、自由な相互批判と、学問の原型への模 索のみである。この目標のもとに、多数の参加 をよびかける。(宇井1970)

ここに凝縮されているのは、学を問い直そうと する意志である。工学部助手会は大学内部の差別 に取り組んだが、宇井はさらに日本の大学の性格 を外から眺めた経験を持ち込んだ。ヨーロッパ留 学で接した、市民の出入りが自由なコレージュ・ ド・フランスの気風や、幾度もの外国軍の占領を くぐりぬけて再建され、街中に民家のように教室 が存在するポーランドのワルシャワ大学の歴史か らすると、企業や権力に依存している日本の大学 は、宇井にとって水俣病の病根に等しかった。宇 井は、水俣病事件を、ただ企業による犯罪とし てだけでなく、学問や教育のあり方が加担して起 きたものと理解したのである。

ゆえに開講にあたって宇井は、聴衆に対し、聴 講料 100 円をとるが、自分の話が面白くなかった り理解できなかったりした場合には返却してよい
と伝えた。それは宇井が自分に課した責任でもあ り、毎回の授業が市民にとって分かりやすく興味 深いものであるよう、相当程度の緊張を強いられ たと回想している。工学部助手会の依田彦三郎も 強調しているように、宇井は自主講座を率いただ けではなく、その中で育てられた（依田ほか 1991 450)。宇井自身も「おそらく自主講座によっ て最も真剣に学んだのは私自身であろう」と述べ ている（宇井1979=2014-1 263）。

\section{3 「実行委員会」の発足と閉講までの経緯}

3 回目の講義の終わりに、以降の自主講座の運営 を支えていく実行委員会が発足した。宇井が次回以 降の準備を手伝う人を呼びかけたところ、10数人 が集まった。実行委員会は、講義の録音テープを 10 分ずつ分担して文字に起こし、講義録を作成し た(宇井編1991 9)。これは冊子として販売され、飛 ぶように売れた。実行委員会には、和光大学、中 央大学、法政大学ほかさまざまな大学の学生や、サ ラリーマン、主婦などがいたが、一番遠いところで は、長野県の塩尻町から車で通う人もあった4)。こ の実行委員会は、宇井の指示で動く「下部組織」 ではまったくなく、議論よりも実務に長け、難しい 仕事でも自然と段取りを決めてこなすことのできる 「ふしぎな性格」(宇井1979=2014-1 264）をもって いた。翌1971年 3 月 18 日まで 13 回を宇井が一人で 講義したあとの第 2 学期以降の方針は、実行委員会 が聴衆の希望をもとに、公害の被害者や加害者側 の研究者の報告を聴く計画を立てていった。宇井 が自主講座「公害原論」に込めた魂は、宇井も予 想しないかたちで実行委員会に受けとめられ、広 がりや豊かさを加えられていくことになった。

自主講座は 15 年間続いた。1979年までのテー マ・講師一覧は、自主講座実行委員会がまとめた 『自主講座十年の歩み』（次頁表 1 ）でご覧いた だきたい (1980〜83年については記録がない) 5)。 講座運営がすべて手弁当に依るこの講座では、講 師も開催頻度も流動的であったが、4学期以降は、 毎月 1 回のペース、顔ぶれの約半数が公害被害者、 住民運動当事者で、残りが研究者や弁護士といっ た専門家というかたちが定着していたようであ 
Whent

ming

(1)

Hentill

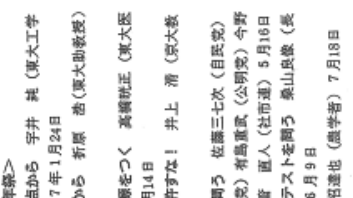

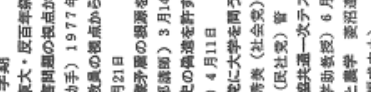

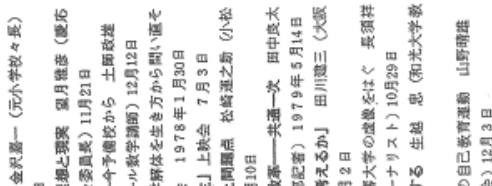

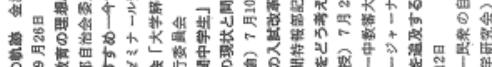
Mimumenting

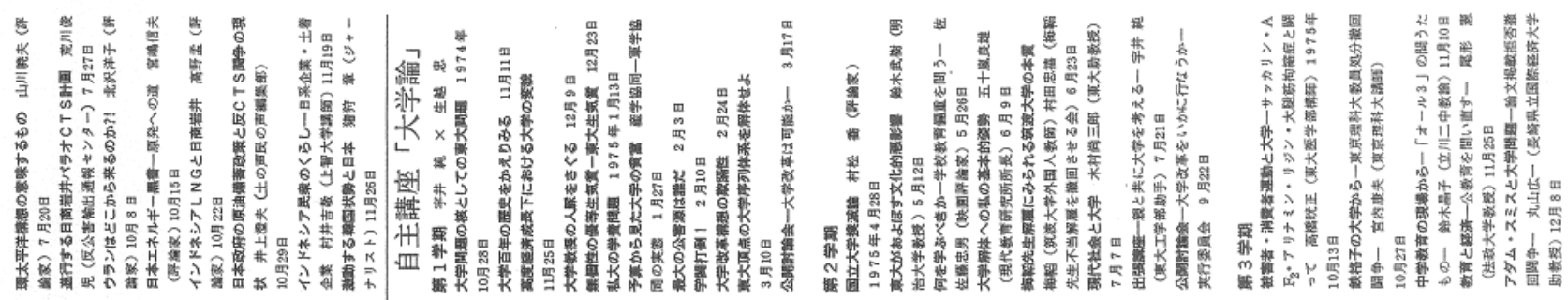

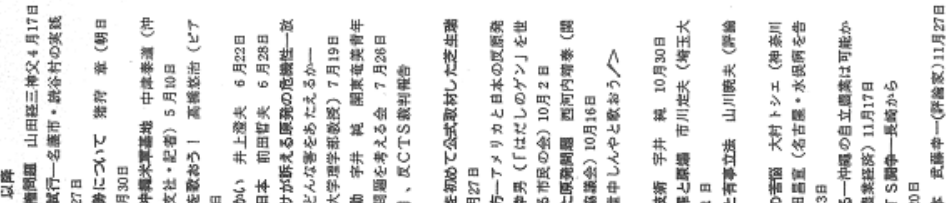

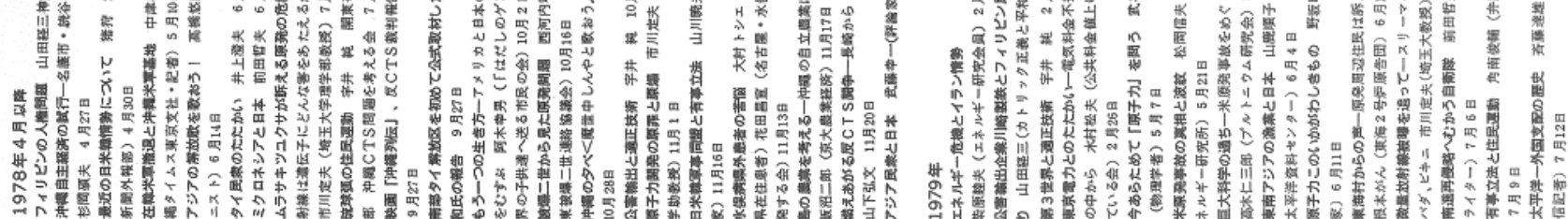

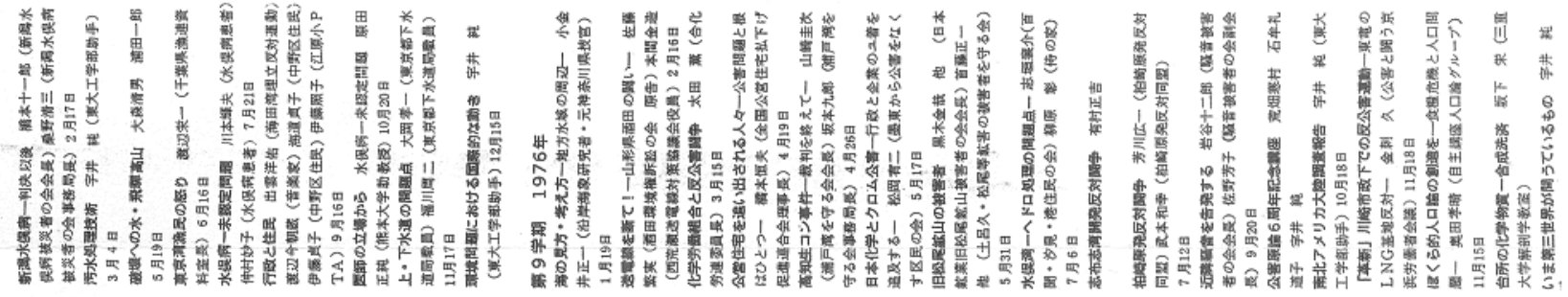

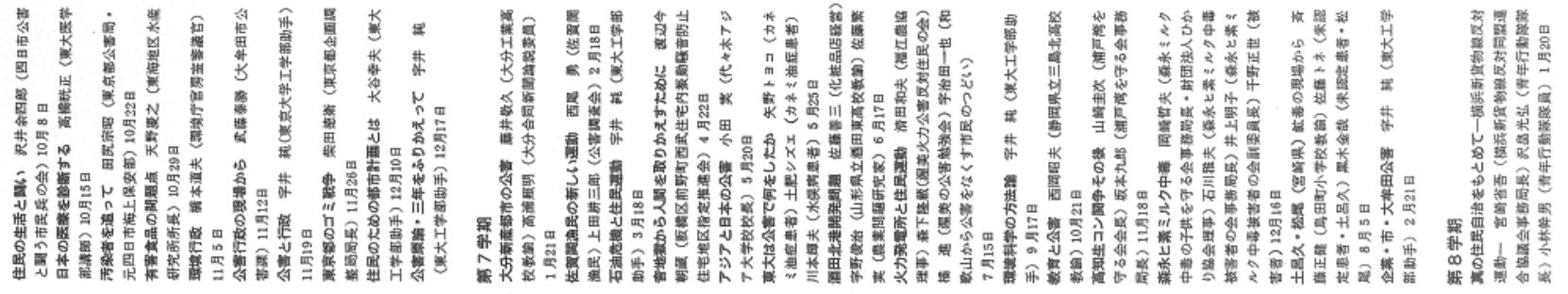

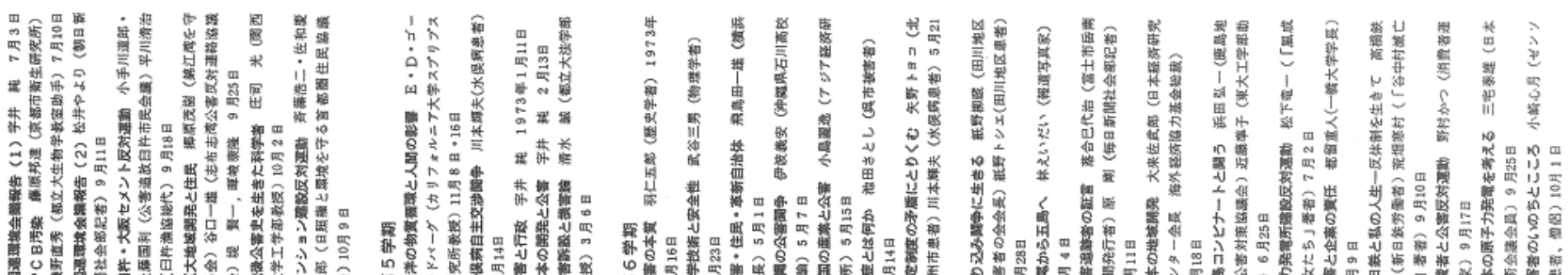

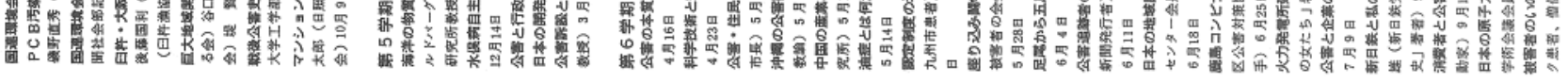
MUnm

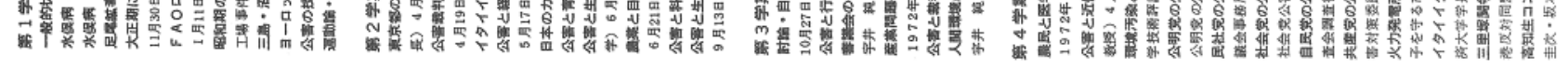


る。参加人数のほうは、初期は盛況で、3回目か らは工学部で一番大きく 400 人ほどは入れる講堂 に移動した。第2学期8回目に荒畑寒村(1887-1981) を招いたとき（1971年 6 月 7 日）は、1000人あま りがつめかけたため、安田講堂前の広場に移動 し、夜空の下での開催となった（朝日新聞 1971 年6月8日)。いっぽう終わりの頃は「一晚に50 人がやっと」だった（朝日新聞 1985 年 3 月 25 日）。 講座以外の場面でもさまざまな動きが並行して 展開した（表2）。1971年4月、各地の住民が必要 とする資料の提供を主な目的として月刊『自主講 座』の発行が始まり、東大の宇井の研究室だけで は仕事が収まらず、水道橋にアパートを一室借り て「自主講座分室」が作られることになった。1971 年 12 月からは水俣病患者・支援者によるチッソ本 社前座り込み行動があり、複数の人がかかわった。 1972 年 6 月の国連人間環境会議に向けては、日本 政府が出した報告書（ナショナル・レポート）の批 判から生まれた冊子“Polluted Japan”の製作活動 があった。東大でだけ講座を開くのではなく、問題 の起こっている現地での「出張講座」も西日本を 中心に実施されている（宇井 1979=2014-1 273274）。さらに、実行委員会が母体となって、さま ざまな活動と媒体（ミニコミ）が「スピンアウト」 した（宇井編 1991 41）。月刊『自主講座』という 媒体を皮切りに、実行委員会では、各地の反公害 運動団体がまとめた資料の交流や、運動現地を訪 れた報告、運動にかかわる情報提供などの作業が 絶え間なく続けられ、そのつどグループができた。 1975年前後には、各グループの定常的な活動が大 きな比重を占めるようになり、自主講座「公害原論」 そのものの内容も提供するようになった。和光大学 教授・埌越忠との「大学論」や、東京大学駒場キャ ンパスでの「駒場講座」なども試みられた。

「多極化」し、「諸グループの連合体のような性 格」に変化した（宇井 1979=2014-1 280-281）自主 講座は、やや停滞を迎える（宇井編 1991 41）。「大 学論」実行委員会のメンバーは、「朝日カルチャー センターと変わらない」という批判を受けて、ほん とうに自分たちは既成の大学教育を問いなおすこと ができているのかと議論している(朝日新聞 1979年
表2 自主講座からの活動展開の一部

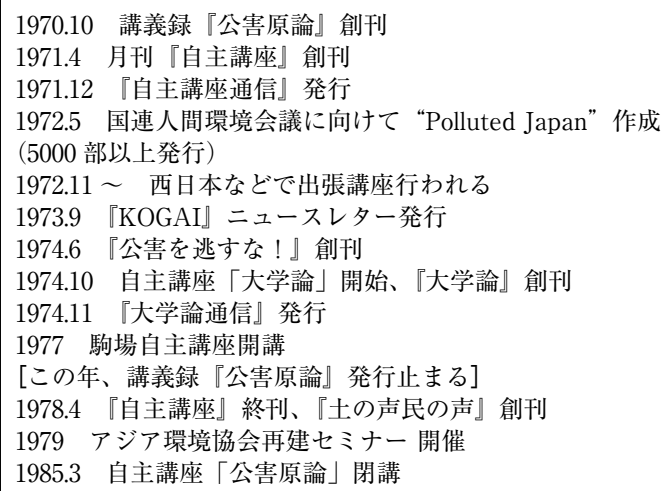

出典：宇井（1991；1979=2014-1） 加筆者作成

11月27日)。肝心の宇井にとっても、東京大学はま すます居心地の悪い場所となっていき (宇井編 1991 50)、一度時間を置くべく、1982〜 83年、アメ リカ・ミシガン州立大学に留学した。そして、州つ てきて企画した産業論の講座 ${ }^{6}$ を最後に、自主講座 「公害原論」はいったん閉じられることになり、 1986年に宇井自身が沖縄大学へと職場を変えるこ とになった。1986年2月5日、宇井は、東大での最終 講義「東大を去るにあたって一一公害研究の反省」 を行い 4 月に沖縄大学法経学部教養科教授に着任 する。自主講座の東大内での代表は依田彦三郎(機 械工学科助手) となり、講座の継続が模索された7)。

\section{4 「電話交換台」としての自主講座}

自主講座「公害原論」が同時代に果たした重要 な役割のひとつとして注目されるのは、全国各地の 被害者、住民運動をつないだことである。前述の「自 主講座分室」が、「全国の公害反対運動の情報セン ターの役割、もっと正確には電話交換台の役を果 たすことになった」のである（宇井1979=2014-1 267)。「電話交換台」とは次のようなことである。

全国のどこかで、たとえば火力発電所や、セメン 卜工場の公害に反対して運動を起こそうという 人の相談を受けると、私たちは全国で最もその 問題について詳しいと思われる知人を探して、 そこへ話をつなぐのだった。もっと自主講座が積 極的な指導をしないのかという不満はよく聞いた 
が、私たちに東京から地方の運動を指導するな んて力はないことを納得してもらった。……地域 ごと、課題ごとにちがう各地の運動にあてはまる 指導的理論を私たちが持ちあわせている自信は なかったし、政党のような大組織と張り合うつも りもなかった。（宇井1979=2014-1 268）

「指導」ではなく、共通した課題をもつ住民同士 をつなげる役割に徹するという志向は、京都で 1970年に設立されたロシナンテ社による雑誌『月 刊地域闘争』（現『月刊むすぶ』）を筆頭として、 1970年代初頭にあった市民・住民運動同士の情報 を揭載する有力な媒体に共通のものだった。紙の 媒体は、1回きりの講座とは違い、人の手から手へ 渡っていき、県境、国境さえ越えて広がった 8$)$ 。首 都圈から遠く離れた場所で、地域の課題に取り組 もうとした人びとが、こうした媒体を手にとり、実 行委員会に電話をかけることがあったのである。自 主講座と各地のあいだに形成されたつながりの広 さは、講座の登壇者一覧にある地域名が、沖縄、 熊本、鹿児島、宮崎、和歌山、三重、富山、愛知、 静岡、新潟、東京、神奈川、茨城、千葉、群馬、 山形、北海道などにわたることが伝えている。

逆に、自主講座実行委員会にかかわった人の中か らも、「“支援”に出かけたまま二度と帰って来な かった若者たち」(松岡1991 477)、つまり、水俣、沖 縄といった地域に移住したり、自分の故郷に帰って それぞれの「現場」をもとうとする者が少なくなかっ た。自主講座「公害原論」は、既存の教育体系の中で は生まれ難い人と人との出会い、経験のぶつかりあ いの場を提供する空間として機能していたのである。

\section{III 反公害住民運動における経験の交流}

では、自主講座実行委員会に連絡をとった反公 害住民運動の側は、どのようにそのつながりを活 かしていたのだろうか。ここでは、筆者が直接話 を聞くことのできた沖縄アルミ工場進出阻止の運 動》について取り上げる。

\section{1 沖縄アルミ工場進出阻止運動}

1970 ～72年にかけて沖縄県石川市 (現うるま市)
で取り組まれたアルミ工場進出に対する反対運動の ようすは、1973年5月7日に開かれた第 6 学期 4 回 自主講座 (テーマ:沖縄の公害闘争) の記録 (図 1) が 伝えている10)。話者の一人である伊波義安は、石川 高校で化学を教える教員だった。琉球大学に1961 年に入学した伊波は、在学中に水俣病事件を知り、 1965年に卒業、新潟水俣病の発生報道や、イタイイ タイ病を診察した萩野昇医師の著書などに触れ、公 害に関心を深めていた。高校の授業でも、こうした問 題を取り入れていたところ、1972年に、教え子から、 アルミ工場の公害について質問された。アルミ精錬 工場からはフッ素化合物による大気污染が発生する (川辺ほか1963)。伊波もこれを教えたが、熱心に何 度も聴くので、なぜしつこく聞くのかと尋ねると、 彼女の父が市会議員で、すでにアルミ工場の誘致 のための調査に行ってきたのだという。危機感を もった伊波は、石川高校の教員仲間とともにアルミ 公害反対に立ち上がり、市内のミカン農家との連 携、「アルミ工場誘 致反対市民協議会」 の結成、市議会への 働きかけを行う。ま た、婦人会と協力し ての学習会は、金武 村、恩納村にも広が り、2回の市民大会の 開催を経て、石川市 が誘致をあきらめ、 県も事実上進められ なくなった。この運 動は、つづく金武湾 CTS建設反対闘争 に合流していくこと になる11)。

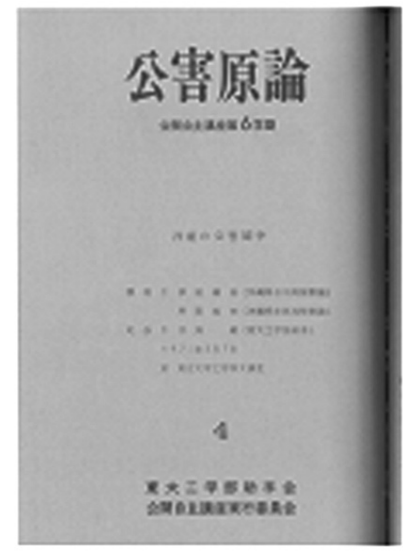

図 1 第 6 学期 4 回講義録 「沖縄の公害闘争」表紙 (協力: 立教大学共生社会研究 センター)

\section{2 本土の公害調査と自主講座実行委員会}

この運動の過程では、市民によるカンパを元手とし た本土アルミ工場の調査が行われている。このとき 頼った伝手が、宇井純と自主講座実行委員会だった。 石川市議会は、1972年4月にアルミ工場の視察に行っ ているが、これは、4泊5日のすべてを企業がお膳立 
てをし、観光地を回り、温泉地で芸者を呼ぶなどし たいっぽう、調査は 4 時間しかしていなかった、と いうことがあとでわかった。市民から突き上げを受け て、市議会が再調査を決めた際、「市民もぜひ調査に 行こうじゃないか」という機運が高まり、カンパを 募って6名が1972年 7 月 16 日〜 26 日の旅程で、公 害の実態を知る調査を実施したのである(石川高校 公害研 1972 12)。

伊波は、運動が始まった当時、書店で宇井純編 『公害原論 I・II・III（1971～72）を買いアルミ 工場に関する情報を求めて自主講座に電話をし、 資料を取り寄せていた。日本科学者会議からも資料 をもらっている。上京した調査団はまず、宇井と実 行委員会のもとを訪れた。宇井や学生らは伊波らを 歓迎し、本土では「長」のつく役職の人間はみな公 害を出す側にいるのに、沖縄ではそうした人びとが 率先して住民運動に立つことに感銘を受けたよう すだった ${ }^{12)}$ 。当初、調查団は、千葉県の市原、静岡県 の蒲原、愛媛県の新居浜を調査するつもりだった が、自主講座実行委員会は、千葉よりも新潟県の 直江津をみるようすすめた。伊波らは、「電話交換 台」としての実行委員の手配のもと、静岡県富士 市の甲田寿彦や富士川町の芦川照江、京都大学の 災害研究グループなど予定外の人びとにも会った。

直江津では、三菱化成から分離した企業「化成 直江津」のアルミ工場が複合大気污染を引き起こ し、周辺の樹木に被害を与えていた。周辺はほと んど農業ができないような状況に見え、これは、当 時石川市で軌道に乗りかけたミカン栽培にも深刻 な影響を与えると予測された。愛媛県の岩鍋地区 では、住友化学関連の工場について、工場内の労 働者はみな防毒マスク、周辺ではフッ化水素で孟 宗竹が被害を受け、歯の欠ける子どもたちが出た などの情報を得た。静岡県の蒲原には日本軽金属 蒲原工場（現在では日本唯一のアルミ精錬工場） があり、やはりかんきつ類への被害があった。これ らの企業はすべて、「沖縄アルミ」に出資すること になっていた。伊波らは、調査内容を逐一、沖縄夕 イムスの記者に報告し、沖縄に伝えた。持ち帰った 野菜や木の葉は、報告会・学習会で役立てられた。

\section{3 経験の交流が生み出す創造力}

だが、この調査のもった意味は、単にアルミ工 場からの公害に関する科学的知見を得ることのみ にとどまらなかったと思われる。伊波は、京大の 関係者に紹介されて、愛媛県でアルミ工場による 孟宗竹の被害を調べている教員と接触したときの ことを鮮明に覚えている。愛媛に着いて電話をか けると、彼は「どこから自分の連絡先を聞いたの か」「絶対会えない、資料は提供するが私からも らったとは絶対言わないでほしい」と言い、伊波 らが泊まっていた宿に、顔を合わせないよう来て そっと資料を届けて行ったという。伊波は、本土 の教員が「非常にオジオジ」している、と感じた。 教員だけではない、住民もまた、なにものかにが んじがらめになっていることを知ったのである。

当初、私、公害調査だけにきたんですが、大資 本の恐さというんですか、企業の論理というん ですかなあ、その恐さを、つくづく感じたんです。 人間の心までもみんな奪い取ってしまうのじゃな いかという意味で私、びっくりしたわけです。… こういうふうになったらもう最後だと、私たちは 前からの意志をよりいっそう固めまして、沖縄に 㷌って来たわけです。(伊波ほか1973 24）

静岡に行った際も、NHKのラジオ番組が調查団 を取材したが、その際、さかんに求められたのは、 本土の教員は表立って反対などということはできな いのに、なぜ沖縄の人びとは教員が先頭に立って反 対運動ができるのかを話してほしい、ということ だった。調査から戻って、地域の学習会を続けるう ちに、住民の意識も、近くに公害源が来てほしくな いという形の反応だけでなく、沖縄のどこにも公害 源を建てさせてはいけないし、恐いのは公害企業だ けではなく大企業そのものだ、という発想に少しず つ変わっていったという（伊波ほか1973 25）。伊 波はとくに、政党やインテリ層ではなく、婦人や農 民、漁民がどんどんものを言う力をもつようになっ たことに、希望を見出していた（松岡 1974 42）。

印象に刻まれる出会いもあった。調査団に参加 した婦人会長の山城とみは、調査当時から 38 年後 
の 2010 年、筆者のインタビューに対し、当時の写 真を見せ、田子の浦のあたりでは製紙工場の臭気 がひどかったこと、愛媛で出会った人とは年賀状 のやりとりが続いたことなどを話してくれた。新 潟では、自分は物は言えないが、あなた方は言え る、がんばってほしいとずいぶん励まされたとい う。そして、どんな人と会ったか、という問いに 真っ先に出てきたのが、静岡県の調査で世話をし てくれた、富士川町に住む芦川照江の名前だった。

芦川（2000）によれば、当時富士川町では、 1968年に発表された東京電力富士川火力発電所建 設計画に対し、過去 30 年にわたって日本軽金属蒲 原工場からの煙害に苦しんできた農民たちが反対 に立ち上がっていた。町ぐるみの反対が静岡県か らの圧力に屈しそうになる危機感の中で、50人足 らずの「富士川町いのちと生活を守る会」が1969 年3月につくられ、運動の核となっていった。芦川 には、 2 人の子どもがいたが、下の男の子は小児喘 息の経験があり、火力反対に立ち上がったのであ る。この会では、農民とともに日軽金のフッ素煙害 の調査を行い、伊波らが訪れたときは、2回目の調 査も終えて報告書が作られている頃であったとみ られる。

芦川（2000）には、このときの沖縄からの来客 についての記述はみられないが、ただ、次に引く 文章は、当時の住民運動が共通にもっていた質 を、的確にすくいとっていると思われる。

自分たちが始めてしまったことが「住民運動」 と呼ばれているものであることさえ知らず、無 我夢中の行動の中で、私たちが得た収穫は随分 大きなものだった。することなすこと、「ああ、 そうか」「ああ、そうか」と覚えること、納得 することの連続で、いつも心は充実し、ほんと うに「生きる」ってこういうことなんだな、と 思ったことだった。…つの運動が次の展開を 生み、やがて他の運動体につながってゆく。 まったくの無知から出発して、思いもかけぬ人 びとに出会い、ついぞ考えてみたこともない結 び目の中に、新しい世界が出来上がっていって しまう。住民運動がもつこの不思議な創造性。
名もなき人びとから人びとへ仲間を求め、師を さぐって、いつしか必要な体制を創りあげてゆ く。(芦川2000 236-237)

必要に迫られて動くことが、「不思議な創造性」 をもつ、そしてそのことが、「生きる」よろこび すらもたらす。山城とみもまた、アルミ公害阻止 の運動だけにとどまらず、婦人会の仕事で様々な 場所へ出かけて行ったことをふりかえって、楽し かった、と話している。外から石川市を訪れた人 が、とみの講演を聴いて、石川には「本当の婦人 がいる」、と評価してくれたこともあったといい、 「婦人会でしか物が言えないというぐらい、婦人 会を強く見てくれた社会のあれが、すごいうれし かった」と話した13)。

普段は異なる場所で、異なる生活を送る者同士 が出会い、感じ考えたことを交換する中から、心 の充実が生まれる。他者の経験と交わることで、 自身の姿が照らされ、あらためて前に進む力を得 るという瞬間がある。1970年代の反公害住民運 動では、このような経験の交流が、大きな役目を 果たしてきた。自主講座「公害原論」と害行委員 会が果たした「電話交換台」の機能は、単に情報 を交換することにとどまらず、当事者たちの運動 経験をめぐりあわせ、たとえ一期一会であって も、その後の人びとの思いや考えの根元に届くよ うな体験を提供していたといえる。

\section{N 「公害教育」における非文字的要素}

宇井が人前で話す際の基本は「経験の伝送」 だった。「どこの事例が成功し、どこの事例が失 敗したか。考えられる原因は何か。その話をして、 聞いた方が自分の行動を決める」ことを繰り返し たのである。宇井は「村から村を旅する行商人」 であり、また「かついで歩く体験が、相手に必要 なものだとわかってもらう」ために表現技術を磨 かなければならないという試練も背負った「旅役 者」なのだという認識にたどり着いた（宇井 1989=2014-3 35-36)。でみたとおり、こうした 実践は、何も宇井だけが行っていたことではな かった。宇井一自主講座実行委員会一各地の住民 
運動が形づくる関係は、経験の交流のひとつの重 要な通り道であったと理解できる。

最後に、これらを「公害教育」と呼ぶ際に捨象され がちな、非文字的要素の存在について考えておく。

「公害教育」の先駆例としてしばしば紹介される 沼津のコンビナート建設反対運動では、鯉のぼり を使って風向調査を行い、亜硫酸ガスの動きを予 測するといった、「科学的公害認識」の成立が高く 評価された (宇井1973c=2014-3 116-117)。しかし 他方で宇井が「科学というものは、決して厳正中 立ではない」（宇井1973b=2014-2 53）と強調する ように、客観性をめざす科学は常に部分しかとら えることができない。宇井は、科学に頼ることの 危うさも繰り返し説いてきた。実際、公害が懸念 される施設が地域に誘致される場合、事業主体が きわめて「科学的」に聞こえる説明を行い、自治 体や議員が納得させられるという失敗の経験は、 石川市だけでなく複数の地域がもっていた ${ }^{14)}$ 。「公 害教育」は常に「科学」であることによる緊張と ともにある。

ひるがえって、東大工学部助手会と宇井純の協 力、自主講座「公害原論」の開始、実行委員会の 誕生、実行委員会が生み出した多岐にわたる活 動、そして、実行委員会が媒介した住民運動同士 の交流。この連鎖反応は、すべて、人と人との出 会いから生み出されたものであった。普段の生活 圈を飛び越えた別の世界との出会いが、自分たち のもっている/もっていないなにかの自覚を促 し、それが、あたらしい学びへの手がかりになる というプロセスは、「公害教育」に取り組んだ人 びとがある程度共通に語る経験である。このと き、わたしたちはつい、そこで交換された科学的 な知見の中身に関心を奪われがちだが、ほんらい 初対面の人びとがまず互いに見合うのは、名刺で も教材でもなく、仕草や声音など非文字的な部分 にあらわれる個々の人間性である。この段階で互 いを信頼することができてはじめて、経験の交流 が生まれるのであり、そこでは、単に相手が有す る科学的知見だけが信頼の対象になるのではな い。再度、伊波の言葉を引こう。
私、“公害教育”なんてのは、ちょっとはうし ろめたさを感じますよ。…“公害教育”という のは、一般に言いますと、有機水銀からどうい う公害が起こる、カドミウムからはどういうも のが起こる、とトクトクとしゃべるんですね。 …ですけど、...公害というものをただメシを食 うために学校で教えるような立場で、…いった い、生徒に教えて生徒に運動をやれと言ってい るのか、それで自己満足をしてつまり運動をし なくてもいいと言っているのか。ですから、案 外、“公害教育”でも隠れミノになる可能性は あるんじゃないか。…私は、あちこちで話をす るときには、単に知識を得てもらうだけでなく て、一緒に闘うことを期待して話をしているつ もりです。(伊波ほか1973 40-41)

人びとが「公害」を科学的に学習し尽くすこと のみでは「公害教育」にはならない。「一緒に闘う」 という言葉には、聞き手の側にも自分の側にも、 部分的な科学的認識をうのみにするのでなく、常 に考える主体であるよう求める、伊波の人間的姿 勢が浮かび上がる。このような伊波たちを迎えた 自主講座実行委員会の人びとは、「沖縄はまだ人 間がいる」「人間らしい人間がいるなあ」と口ぐ ちに言ったのだった ${ }^{15)}$

火力発電や原子力発電の有害性を語るには、あ る程度科学的知見への理解がなければ難しい。し かし、科学的なことばをいくら注ぎ込んでも、相 手の内面に呼応するものがない限り、公害のひど さもこわさも、情報として処理されて終わってし まう。つきつめれば、「被害者は、公害を体全体 でつかまえている」(宇井1973=2014-2 48）とい う不動の事実を共有することができるのかという ことでもあろう。「一緒に闘う」ことの意味は、 あるいは、「うしろめたさ」を意識しながら前に 進もうとするひとの複雑さを、丸ごと共有できる のかという問いかけであるかもしれない。

自主講座「公害原論」は15年間で幕を閉じた。 しかし、自主講座を通り抜けた反公害住民運動が もっていたいきいきとした活動の経験には、学校 教育、社会教育という範囲を問わず、学びとは何 
か、という根本を考える際の有効な手がかりが、 まだ数多く眠っているように思われる。

付記＼cjkstart本稿に関するすべての責任は筆者にある が、住民運動と自主講座「公害原論」のとらえ方 は、筆者独自のものというよりも、住民運動当事 者の方々や市民・住民運動資料の保存 - 活用にか かわる方々の間で共有されてきた認識を筆者なり に再解釈したものである。関連するすべての方に 御礼申し上げる。

\section{注}

1) 実行委員のひとりであった亜紀書房の整田金 治が編集した宇井純編『公害原論』(1971) は、 毎月重版が続き、のちに『週刊朝日』誌上で 「戦後日本を変えた 20 冊」に選ばれた（霜田 1991 485)。

2)「現代技術史研究会」については井野（2013） を参照。連載はその後会員仲間で合化労連に いた近藤完一の取り計らいで『月刊合化』に 移動した。

3) 初回の講義を最前列で聞き、のちに実行委員 会の中心人物となる松岡信夫は、「ものすご い熱気」の中、このことばに「ジーンと来て、 燃え」たという（松岡1991 464）。松岡は宇 井と同い年で、大学卒業以来勤めてきた通信 社の記者を辞めたばかりだった。

4) 昭和電工塩尻工場の粉じん公害に取り組んで いた三浦敏正氏（三浦 1971）。宇井の自主講 座15年を振り返る著書の冒頭は同氏の逝去 の報で始まる（宇井編 1991:3）。

5)この表は、A3から縮小したため判読しづら く、また、一部氏名の䛊記や日時の前後、情 報の抜けなどがあって完全ではないが、当時 を示す貴重な資料であるため転載させていた だいた。より正確な表は、2007年6月 23 日 に東京大学で開かれた「公開自主講座『宇井 純を学ぶ』」当日配布冊子の 25-28頁に埼玉大 学共生社会研究センター（藤林泰、谷中照枝、 平野泉）と筆者で作成したものを参照。

6) 最後の年の講座内容は、宇井編（1986）と朝
日新聞 1985 年 1 月 22 日記事を参照。

7) 自主講座の終わりについては、工学部での自 主講座運動は、「自主講座『設計論』『廃裹』 をもって幕を閉じた」（依田2008 157）と いう記述や、自主講座「水俣学」の講座（講 師：最首悟氏）が廊下を使って行われたとい う記事（朝日新聞 1987 年 6 月 20 日）などが あるが詳細は整理できていない。今後“宇井 中心史観”ではないかたちで自主講座運動の 歴史をみなおす作業も必要である。

8) 宇井の耳にしたエピソードでは、韓国の反公 害運動のリーダーの一人が、獄中にいた際、 同房だった人権運動の指導者・徐勝氏に差し 入れられた『公害原論』を、徐氏の訳で読んだ というものがある（宇井1996=2014-2 175）。

9)「沖縄アルミ」とは、アメリカ資本のアルコ アが、施政返還直後の沖縄に進出しょうとし たことに刺激された本土のアルミ精錬5社(日 本軽金属、昭和電工、住友化学工業、三菱化 成工業、三井アルミニウム）が、1972年 12 月に立ち上げた現地法人である。屋良朝苗琉 球政府主席は本土「復帰」に向けて積極的に 工場を誘致しようという姿勢を見せ、通産省 と歩調を合わせていた。

10）以下、伊波ほか（1973）、宇井（1971）、森山 (1972)、石川高校公害研（1972）および、伊 波義安さん、山城とみさんのお話（2010年3 月 4 日、9月9日、うるま市）を基に記述する。

11) 1973 年以降のCTS 反対闘争に取り組んだ人び とについては上原 (2014) を含む連載が詳しい。

12) 2010 年 9 月 9 日、聞き取りより。

13） 2010 年 9 月 9 日、聞き取りより。

14）たとえば愛知県の「渥美火力の公害に反対す る住民の会」に参加していた渥美町会議員 は、中部電力の案内で尾熟火力発電所を見学 し、亜硫酸ガス測定器を 5 カ所つけているな どの説明を受けて、「今でいえば恥しいこと ですが、感心して来た」「コンビナートじゃ ないからいいだろうとみな思い込んだ」（渥 美の公害勉強会1973 58-59）と悔いている。

15) 2010 年 9 月 9 日、聞き取りより。 


\section{引用文献}

*宇井純の著作中、「初出年 $=2014-\mathrm{x} 」$ で表記したも のはすべて藤林泰・宮内泰介・友澤悠季編 (2014) に収録された記事であり、 $\mathrm{x}=1,2,3$ は収録巻を示す。

安藤聡彦, 2015, 「『公害教育から環境教育へ』再 考」, 佐藤一子編『地域学習の創造一一地域再生 への学びを拓く』, 東京大学出版会, 東京 : 51-74. 芦川照江, 2000, 『そのとき住民は一一富士川町の 住民運動私記』, みどり美術印刷株式会社出版 部, 静岡, 394pp.

渥美の公害勉強会, 1973, 『火力発電所もういらな い一一灭力害に反対する全国住民運動交流集 会の記録 1972.9.23-24』, 愛知, 191pp.

藤林泰 - 宮内泰介 - 友澤悠季編, 2014, 『宇井純七 レクション 1 原点としての水俣病』(410pp)， 同『2 公害に第三者はない』 $(382 \mathrm{pp})$, 同『3 加害者からの出発』(386pp), 新泉社, 東京. 伊波義安・照屋唯夫・宇井純, 1973, 「沖縄の公害 闘争」『公害原論』(第6学期 4 回、1973年5月 7 日), 公開自主講座「公害原論」実行委員会, 東京, $51 \mathrm{pp}$. 井野博満, 2013，「6-20 技術者の運動一一現代技 術史研究会の活動を中心に」『技術史研究』81:1630.

石川高校公害研, 1972,「〈住民運動報告〉沖縄ア ルミ進出と市民運動」『自主講座』18：5-17.

自主講座実行委員会編, 『自主講座十年の歩み』

（A3両面刷り資料，発行年記載なし），立教大 学共生社会研究センター所蔵.

川辺亘 - 竹内重二 ・ 松下武彦 - 津田豊彦 - 伊藤英 一, 1963,「アルミ精錬工場の弗素化合物による 大気污染について」『産業医学』5(3):291.

松岡信夫, 1974, 「ヤマト幻想は破綻してゆく— 沖縄のCTS反対闘争が示すもの」,『朝日ジャー ナル』16(8) : 39-43.

松岡信夫, 1991,「自主講座が生れたころ」, 宇井 純編 1991:463-481.

三浦敏正, 1971，「〈各地から〉粉じん公害の告発 へ」，『月刊地域闘争』,8,62-63.

森山賢太郎, 1972,「〈住民運動報告〉沖縄アルミ
進出に反対する」，『自主講座』17:19-25.

霖田金治, 1991, 「自主講座開講前後—思い出す ままに」宇井純編 1991:482-485.

上原こずえ，2014，「《沖縄・分断にあらがう (4)》 抵抗運動の連帯と『境界』に対峙するための言 葉」,『季刊ピープルズ・プラン』64:9-13.

宇井純, 1970,「開講のことば」,『工学部助手会

ニュース』3:7. (立教大学共生社会研究センター 所蔵)

宇井純, 1971，「沖縄の公害と住民運動」，『自主

講座』3:11-16.

宇井純, 1973a，「科学は信仰であってよいか一 だれのための学問か」=2014-1:306-310.

宇井純, 1973b，「公害に第三者はない一一公害と

住民生活」=2014-2:35-69.

宇井純, 1973c，「住民運動の作る科学」=2014-3：

110-127.

宇井純, 1979, 「東大自主講座 10 年の軌跡 (上)

一一民衆に支えられた『公害原論』」「同（下）

一一自主講座連合としての大学づくりを」= 2014-1:260-290.

宇井純, 1980,「住民運動と学習——新寺子屋論」 $=2014-2: 248-251$.

宇井純, 1989,「経験の行商人、旅役者を目指して」 $=$ 2014-3:33-39.

宇井純, 1996, 「地球環境時代における足尾鉱毒事 件の意味」 = 2014-2:164-183.

宇井純, 1997, 『キミよ歩いて考えろ——ぼの学 問ができるまで』, ポプラ社, 東京, 237pp.

宇井純, 1999,「自主講座『公害原論』の体験」= 2014-1:291-295.

宇井純編, 1986, 『未来産業の構造一一先端技術を めぐる対論』亜紀書房, 東京, 234pp.

宇井純編, 1991, 『公害自主講座15年』亜紀書房, 東京, 501pp.

依田彦三郎・高橋昇・安川栄・松岡信夫, 1991,

「座談会 自主講座を生み出したもの」, 宇井 純編 1991:445-462.

依田彦三郎, 2008,「自主講座（運動）を語るキー ワード」宇井紀子編『ある公害・環境学者の足 取り』亜紀書房, 東京:156-157. 